\title{
Some Perspectives on Redundancy With Special Reference to the State Dockyard, Newcastle, NSW
}

\author{
Edward J. Burke*
}

The purpose of this article is to focus attention on the decision process which made over a thousand men redundant at State Dockyard, Newcastle, NSW. In the past, attention has been focused on labour market effects with social issues almost entirely neglected. We seek to highlight the imbalance of power which exists between employer interests, trade unions and workers. Dockyard workers endeavoured to resist redundancy and their means of protest were a reflection of the power base available to them. What emerges is an inability of workers to successfully resist redundancy.

\section{Redundancy - Introduction}

Redundancy represents a severe social and economic problem for workers particularly when unemployment is increasing regionally and nationally. An Australian Federal government decision, towards the end of 1976, to have two ships for the Australian National Line (ANL) built in Japan ensured the redundancy of about 1,150 manual workers and 150 administrative and technical staff at the State Dockyard, Newcastle, NSW. This represented about two thirds of the total work force. Redundancies of such magnitude in a specific industry have been rare in Australia (at least since World War Two). The trek out the gate began in October 1976 and continued until the total work force was reduced to about 550 men 12 months later. Those men who remained were engaged mainly on ship repair and general engineering work.

Redundancy is not a new phenomenon. It has been with us for hundreds of years. However, since World War Two, the concern for full employment policies in most western economies has brought greater recognition and increased publicity for people who have been made redundant. "Circumstances and attitudes have changed radically from the nineteenth century notion that employees harshly affected by technological change should bear the brunt of their misfortune without help." 'Several European countries have introduced redundancy legislation ${ }^{2}$ and, following the 1963 Richard's report, the NSW State government legislated for those cases where redundancy was caused by technological change. The South Australian Industrial Court has also exercised its jurisdictional powers in this respect. ${ }^{3}$ Nevertheless, these actions do not satisfy an Australian Council of Trade Unions (ACTU) requirement of four weeks pay for every year of service. Generally, Australian initiatives have relied upon trade union power to secure monetary compensation which is either written into awards or negotiated on an ad hoc basis.

\footnotetext{
* Senior Lecturer, Faculty of Economics and Commerce, University of Newcastie, Australia.

1 Yerbury (1973, p.254). Redundancy at the Dockyard was not caused by technological change, however, Yerbury's comment has general applicability.

2 Employment Protection Act 1975, paras 44-46. Sweden, West Germany, Belgium, Holland and France have various statutory provisions regarding redundancy.

3 As a result of Mr Justice Richard's report (1963), a provision in the Industrial Arbitration Act of NSW, Section 88G, provides for insertion into an award or agreement of not less than three months' notice of an impending redundancy. The South Australian Industrial Court has ruled that a Commissioner has power to include in an award provisions for redundancy. (See Federated Miscellaneous Workers' Union (SA) v Adelaide Milk Supply Co-Op Ltd, [1978] AILR 418 and 528. See also Fisher, (1969, p.212). The recent Commonwealth Employees (Redeployment and Retirement) Act 1979 provides six months and 12 months notice of redundancy for public servants. There is also a right of appeal.
} 
The social aspects of redundancy have received insufficient attention in the literature. As Wood noted, "The central concern is in how redundants fare in the labour market". (Wood, 1977, p.52) Most studies have emphasised economic considerations and dealt with redundancy from the point of dismissal. These date from Kahn (1956), Wedderburn $(1964,1965)$, Sams and Simpson (1968), Mackay and Reid (1972), Daniel (1970, 1972), and Herron (1972, 1975). Admittedly some researchers have acknowledged social and psychological effects and state more could be done, although in what way is not made clear.

The Department of Productivity, in 1977, began a survey of redundancy procedures in Australia. Their survey of four industry groups showed 282 companies had at one time or another experienced redundancy. (Pouncz, 1979) However, apart from the recent research of Aungles and Szelenyi (1979) into redundant shipyard workers at Whyalla, and that of Smith (1978) who investigated the experiences of 60 textile workers, redundancy has received scant attention in Australia. Redundancy would probably not be an issue at all if full employment still existed in Australia.

\section{What is Meant by Redundancy?}

The growing criticism that redundancy research has been too limited in scope and concentrated almost exclusively on labour market effects may arise from the meaning redundancy conveys to those analysing it. In many human situations effects are observable and can be subjected to measurement by the observer, whereas causes on the other hand are buried deep in human consciousness, rooted in social mores, craft traditions and as a result, difficult to pinpoint. For example, it is generally easier to examine the effects of a strike than it is to uncover the causes. Clearly redundancy as a word in general use conveys something surplus or unwanted and no longer useful. This may be why most research has been in the area of post-redundancy. Answers to questions why labour has become surplus to requirements are couched usually in rational economic terms with passing reference only to social implications.

One of the earliest post-World War Two redundancy studies was conducted by Kahn (1956). Kahn recognised that the social and economic aspects of redundancy are not discrete. Redundancy is defined, "... as applied to human beings is an excess or superfluity of labour, due to a change - however caused - in some aspect of the market situation". (p.19) Since Kahn's study is concerned with labour market mobility and the ease or difficulty of finding a job, her attention was focused on effects and not creation of redundancy. Redundancy is accepted as a given and an inevitable feature of market mutations. The underlying factor which causes market changes may be a feature of the social and economic order. By whose decree does labour become surplus? This opens the matter of power relationships. It might be argued that the spirit of capitalism is a major cause in that labour can be expelled like an evil spirit in order to protect capital. Since Kahn's work appeared, the concept of "property rights in a job" has arisen to challenge the hegemony of capital over labour. Many European countries during the last decade have reported major work-ins, sit-ins, or plant occupations. ${ }^{4}$

The OECD in a redundancy study which contrasted four separate industries in the USA and UK defined redundant workers - ".... comprises those who need to make a permanent adjustment as a result of lasting structural changes, not as a consequence of cyclical or seasonal factors". (Smith, 1966) The OECD version is wider in scope than that of Kahn. A structural change could arise from a number of reasons not restricted to market mutations. However, the criticism offered against Kahn's view of redundancy is also applicable to the OECD version. While the effects of redundancy are important as part of the total redundancy situation, the preredundancy decision and how it arises should be included in any definition of redundancy.

4 For a discussion of worker sit-ins, see Mills, (1976). 
Sole concentration on post-redundancy overlooks the importance of power and its distribution in society. Power in the final analysis is exercised unilaterally because of the hierarchical nature of our society. The rank and file seldom have an opportunity to provide alternatives and reject redundancy altogether. Plans are often made in secret and released as a fait accompli to trade unions and workers who have very little time to muster countervailing power. As Wood has noted, workers are forced out. (Wood, 1977, p.58) Clearly if a minority group can force out another larger group, the former relies on power to achieve its aims. Hence power emerges as an important ingredient of redundancy creation.

Furthermore workers are forced out through no fault of their own. On occasions it may appear that workers have contributed to their own demise by persistent go-slows, and the disruptive tactics of agitators, etc. This reasoning cannot be sustained and is misleading. It fails to acount for the socio-economic structure, the institutional arrangements and the climate of industrial relations.

Redundancy creation and the treatment of redundant workers is fundamentally dependent upon what society is prepared to tolerate. When redundancies occur, workers are forced out despite resistance and presumably through no fault of their own. Hence redundancy is a situation in a socio-economic structure where an elite group uses its power to rescind the jobs of another group for whatever reason, forcing them despite resistance (if any) to leave the work place with no foreseeable prospect of re-engagement.

\section{Redundancy at State Dockyard, Newcastle, NSW}

The role played by the Industries Assistance Commission (IAC) and the Federal government as actors in the events leading up to redundancy deserve attention for the government used the IAC report as the mainspring of its actions which created redundancy. The Federal government on 18 August 1976 asked the IAC "whether in the light of cost movements in ship building since the Tariff Board" last reported in 1971 any changes are necessary in the assistance accorded the industry in order to sustain economic production in Australia"'. (IAC, 1976)

One month later, the IAC reported: "The Commission concludes that the production of large vessels by Dockyard and BHP is now and is likely to remain, uneconomic". (IAC, 1976, p.75) The IAC noted that no real attempt had been made by shipbuilders to divert resources to small ship construction as recommended in the 1971 report. If this prior recommendation had been adopted, excess capacity in small ship construction may have been the result of BHP and State Dockyard entering that sector of the market. The effective rate of assistance currently afforded local production was noted by the IAC to exceed 100 percent for larger ships. (IAC, 1976, p.74) The IAC referred to the multiplicity of trade unions and the disruptive effects of demarcation disputes.

While cogent argument can be developed to favour amalgamation of trade unions, demarcation disputes were not unique to State Dockyard and in any case, multiple unions are a common feature of Australian labour organization. Secondly, protection in the form of subsidies, tariffs and import quotas is provided over a wide range of Australian rural and secondary industries. Shipbuilders in European countries are granted a number of protective measures against foreign competition. Credit facilities, research contributions, fiscal assistance, direct subsidies etc., are but a few. (OECD, 1976) Shipbuilding since time immemorial has been subject to sudden cyclical variations in supply and demand. Many countries have sought to protect shipbuilding from sudden fluctuations and marginal pricing competition particularly from Asian yards.

5 Predecessor of the Industries Assistance Commission. 
The NSW and South Australian State Labour governments in their evidence to the IAC admitted shipbuilding needed reorganisation. The NSW government asked for special assistance to permit re-equipment and modernisation at State Dockyard. Dockyard management had made repeated pleas for nearly twenty years to their State minister, first for a graving dock and later a floating dock. The Dockyard had known only shoe string financing since its inception during World War Two.

The usual prevarication between State and Commonwealth governments appears as a major reason why a comprehensive long term modernisation programme did not eventuate at State Dockyard. Neither government wanted to accept full responsibility. The State government was the employer but thought the Federal government should contribute financially towards a major modernisation because of the defence link. The Federal government apparently wanted no further involvement beyond its subsidy contribution.

BHP was the only ship operator to make a submission to the IAC " .... that the costs of any scheme recommended by the Commission to support shipbuilding in Australia be borne totally as a community cost and not as a cost to shipowners and ship operators". (IAC 1976, p.6) The BHP submission indicates a curious attitude to state and private capital arrangements. The BHP case while directed presumably at their own shipyard in Whyalla, South Australia, may well have contributed indirectly to the Federal government's attitude to shipbuilding late in 1976. (Aungles and Szelenyi, 1979, pp.29-32)

Shipping industry submissions to the IAC emphasised non-economic issues. These related to defence, the island continent and social effects on the region. The IAC rejected these arguments. The Federal government's reference to the IAC was confined to economic issues. The IAC in the light of submissions made to it, did examine human effects of unemployment (IAC 1976, pp.79-83) but they were not analysed in depth because personal hardship was measured in economic terms only, presumed to be short run and dependent on the job market. As it happened, many skilled tradesmen had to accept work outside their trade - often unskilled work - and many could find no job at all. A number finished up leaving their trade in disgust.

The IAC would probably claim: first, they must adhere to their terms of reference and secondly, since they are an advisory body, it is for government to decide whether the hard cold facts of economic logic need modification; since federation Federal governments have often done so, particularly in the rural sector.

Since people do not live their lives entirely according to the strict tenets of economic logic, advisory bodies such as the IAC should be restructured to provide more broadly based reports which emphasize the social consequences of economic advice. Skilled advisors are required in areas other than economics, otherwise the imbalance of policy rccommendations based on rational economic man (a mythical and inhuman figure) will on many occasions continue to create human misery.

It could be argued that the Federal government and advisory bodies such as the IAC function as integral components of the ruling elite structure - pawns in the interests of capital. Capital is a much more mobile factor than labour and can be withdrawn and reinvested where its economic return will be highest. If excess supply occurs because of previous over-investment, then capital is withdrawn and reinvested elsewhere.

The Suez crisis created a heavy demand for larger ships which resulted in worldwide excess supply and shipbuilding in Australia faced a bleak period from 1974 onwards, especially with marginal cost pricing competition from Asian shipyards. Ships built in Australia were no longer competitive and could be purchased much cheaper from
overseas yards.

Following BHP's intention stated to the IAC to retrench 1,720 employees at its own Whyalla shipyard by mid-1978, the Federal government was not disposed to offer an increased subsidy to State Dockyard. Nor is Newcastle important politically to a conservative Federal government since the city returns huge majorities for the Labour
Party. 
The Federal government's refusal to increase the subsidy and the placing of orders for two new ships with Japanese yards invited serious questioning of the socioeconomic order. What was forgotten was that many men had invested a considerable portion of human capital in the industry. They were invited to work at the Dockyard when shipbuilding was considered economically viable. Later when shipbuilding was considered uneconomic, labour was dispensed with and men were thrown on the job market with little concern for their welfare.

The IAC was aware of the redundancy spectre facing Dockyard workers and their prospect of finding alternative employment at a time of escalating unemployment in the Hunter Valley. (IAC 1976, pp.77-79) Hardship was experienced by many skilled metal tradesmen and electricians. The IAC recognised the unemployment multiplier effects in industries dependent upon Dockyard contracts. However, the human hardship argument did not deter the IAC from its main course: ".. it appears probable that construction of large ships must cease sooner or later and postponement of such action would only increase the costs involved". (IAC .1976, p.76) So the preservation of economic capital prevailed over human capital. The spectre of human redundancies will not disappear under such circumstances. Nor will the efforts of manpower planning be beneficial, if the interests of capital predominate. In fact, it could be argued that manpower planning is not essential to a capitalist economic system if human redundancies are to be accepted as an inevitable feature of economic progress.

It should not be assumed that economic considerations are unimportant. The efficient use of resources at individual or national level is a desirable aim but not at the almost total exclusion of the rights of human capital. In an advanced economy, capital and labour need each other.

It is more than a reasonable surmise that the Federal government expected the IAC to conclude as it did after the latter's 1971 report. Commercial shipbuilding in Australia had been leading a hand to mouth existence for many years. This contributed to a high degree of employment uncertainty in the industry for both management and workers. Our survey of ex-Dockyard workers showed that only 13 percent were greatly surprised when the official decision to retrench came through.

Did the IAC merely endorse the inevitable? Their terms of reference were confined to economic criteria. Had the IAC been given a wider brief to investigate a restructuring of the industry and a modernisation programme, the recommendation may have been different, particularly if in-depth social research had been carried out. Instead, workers were the victims of over twenty years of negligence.

Evidence to the IAC 1976 enquiry showed that $\$ 40$ million to $\$ 50$ million would be needed to modernise facilities at State Dockyard. The yard's equipment and layout necessitated double handling during ship construction. (IAC, 1976, p.25) Our own survey revealed that workers were very critical of the state of technology, equipment and inadequate capacity. Yet the standard of craftsmanship was high and praised frequently by shipowners and crew as being second to none. It is difficult indeed to compete on favourable terms indefinitely and tender against overseas yards who have not only modern technology but strong support from their governments.

Early in 1977, a decision was made by the NSW State government to purchase a floating dock for ship repair work. The Federal government refused any financial sharing with the State government. However, the State government claimed it could not afford the millions of dollars required for modernisation without Federal government assistance. In spite of higher service charges on investment capital, earlier modernisation may have made the Dockyard more competitive.

The IAC also noted, “... scaling down would cause social and regional problems, which the Commission suggests should be reduced by the provision of adequate assistance". (IAC, 1976, p.76) What assistance the Commission had in mind was not 
disclosed. The Federal government ignored the suggestion altogether. No special assistance was provided for redundant Dockyard workers other than what was normally available. Most men initially sought assistance from the Commonwealth Employment Service (CES). The CES was not given extra staff to cope with the task of finding jobs for hundreds of redundant men. The CES also provided an on-site service at the Dockyard but could do little to assist redundant workers because unemployment was already high for many of the occupational skills held by Dockyard workers. Men who found jobs did so mainly through friends, relatives and by calling on firms personally. The remainder had to accept unemployment benefits, the maximum assistance provided by the Federal government. As stated earlier, the Federal government was safe in the knowledge it had nothing to lose politically. If the Newcastle region had had one or two marginal parliamentary seats, government policy may have been different.

The Federal government did make an offer unilaterally on a take it or leave it basis; they would increase the subsidy for construction of two ships at the State Dockyard for the Australian National Line (ANL) from 35 percent to 59 percent provided the NSW government and trade unions signed a 13 clause contract. The key elements of the contract were, (i) no wage increases other than wage indexation; (ii) no change in conditions which would add to costs; (iii) no strikes, bans, demarcation disputes; (iv) if completion was delayed beyond the contract date, the ACTU and trade unions to pay liquidated damages. Furthermore the NSW government (as employer) was required to indemnify ANL if any breach of the industrial relations contract occurred. An extraordinary and unprecedented feature was the non-negotiability of the industrial contract. The Federal government indulged in a blatant abuse of power which was to become known in industrial relations circles as "crashing through". Surely here was an example that pluralist devotees would not wish to recall. There can be only industrial anarchy without negotiation - something trade unions are told frequently.

A more positive and constructive approach would have been for the Federal government to have entered into a joint shipyard financial agreement wth the NSW government. To have offered to undertake a complete restructuring of the Dockyard and to modernise facilities in consultation with the NSW government, Dockyard personnel, the ACTU and trade unions. This would have removed much of the uncertainty and insecurity which had plagued the Dockyard for many years. The Dockyard malaise should have been conceived of as an industry problem and not by attaching blame to any one group. Certainly not trade unions, who most often react to decisions in which they have had no prior participation. A genuine and sincere form of industrial democracy may well have led to constructive improvements.

In the light of hindsight, it appears the Federal government's non-negotiable package was designed to be rejected by the ACTU, trade unions and the men. If it had been accepted, the style of "crashing through" may have become more widespread and open industrial warfare a distinct possibility. The ACTU and trade unions were well aware of the dangerous precedent behind the Federal government's proposals. It was beyond trade union power to accept the principles inherent in the proposals.

The NSW premier thought the offer was designed to provoke the reaction which the unions had made. The local city newspaper in an editorial stated, "The government did not make an offer; it proposed a form of industrial bondage that was completely outside the mainstream of Australia's recent industrial history and contemporary experience." (Newcastle morning herald, 24th November, 1976) The insensitive statements of one or two Federal ministers appeared to indicate the Federal government's intention to dismantle shipbuilding irrespective of evidence placed before it. A full meeting of Dockyard workers rejected the Federal government's industrial contract and became martyrs for their industrial principles. The Federal government placed orders for two ships with Japanese shipyards soon afterwards. 
Several Federal ministers echoed the view that Dockyard workers were irresponsible and strike prone; a widely disseminated view held generally in the Newcastle region and other parts of Australia. The saga goes back to earlier coal mining disputes when other Australian cities, reliant on Hunter Valley black coal for electricity generation, experienced winter blackouts. Unfortunately full regional data on industrial disputes does not exist to disentangle fact from myth. Fortunately regional dispute figures have been available for coalmining and stevedoring. Gordon has shown that for ten years 1965-66 to 19/4-75, "the coalmines on the Newcastle field have only twice exceeded the annual State average for the percentage of man-shifts lost due to industrial disputes. The South Maitland mines have been in excess of that average in only one year. Turning to the waterfront ... Newcastle waterside workers have been significantly less dispute prone than their counterparts in other major ports."' (Gordon, 1977) Gordon provided data from official reports to substantiate his remarks. Full regional statistics on industrial disputes may well explode the myth that Newcastle workers are dispute prone.

Dockyard management, trade unions and workers reacted vigorously to the Federal government's action. Protest was voiced by the City Council and various civic groups in Newcastle. Evidence from the influential Hunter Valley Research Foundation was sent to Canberra. Management confined themselves mainly to official channels of the State government network. The threat of closure naturally brought management and trade unions together.

The means of protest available to trade unions and workers was determined by their inferior power base. They were not made privy to Federal government decisions and were generally the last to receive information. Lack of prior consultation placed trade unions in a rectionary situation. Despite their disadvantaged position, the men were prepared to resist and resorted to various forms of protest to convey dismay at their plight and a refusal to accept what they saw as an injustice. Massed meetings of workers were held to plan counter actions. Street marches were held in Newcastle to enlist local support. There was a meeting with the Japanese Ambassador and a temporary ban was placed on Japanese colliers. Several bus trips were made to Canberra to lobby Federal parliamentarians. A three man committee had a fruitless interview with the Prime Minister and a tent embassy was erected outside Parliament House, Canberra. The Dockyard Works Committee sought the intervention of the influential ACTU President who came to Newcastle but his efforts also proved fruitless.

Often the men's actions drew censure from governments, news media and community groups, who misunderstood the strong feelings of pride possessed by shipyard workers. Theirs is a craft industry and men identify with every ship. Witness, for example, the rites at shiplaunchings. The men wanted to keep on building ships and preserve their jobs. These and other traditions helped shape the men's conflict stance to redundancy. Shipbuilding, as with coalmining and stevedoring, has a long tradition of drawing battle lines. the relationship between conflict and industry structure is not always well understood by observers. (Eldridge, 1968)

After about three months, the men's efforts proved abortive. The Federal government would not budge from its industrial relations contract. The ACTU and trade unions were forced to accept the lack of power in their situation. Another victory had been posted for the ruling elites. The only thing left was to fight for the best conditions on behalf of potential redundants.

Work-ins, and sit-ins have received a lot of publicity as a form of worker protest against redundancy in overseas countries. Work-ins hold tremendous implications for the future of trade union organisation, employee relations and organisation of industry. As a form of protest work-in was not available to shipbuilding workers at State Dockyard. Obviously orders were needed to build ships, with large financial 
reserves, sympathetic governments and co-operation of management. Besides the time horizon between notice of redundancy and shipbuilding cessation was too short to consider alternative products.

The State government as the employer did attempt to save some jobs by its decision to order a new floating dock from Japan. Orders were placed for two small harbour ferries and a hundred school class room demountables. The State government did establish a task force to advise it on the future potential of the Dockyard. The State government was unable to place many Dockyard tradesmen, semi-skilled and unskilled workers in public employment in Newcastle and very few men were prepared to leave Newcastle and reside in Sydney.

Considerations of financial compensation dominate redundancy policy in most countries. Economic difficulties faced by redundants are certainly important. However, job security often means much more to the average worker (Seglow, 1970, p.7) Paterson has observed that workers will often opt for money because they have so few opportunities for capital accumulation and readily accept the financial compensation to buy a new car, to refurnish, to reduce home mortgage etc. (Paterson, 1978) The concept of property rights in a job have not made much headway as yet in Australia. Perhaps there was little need for concern until serious unemployment levels emerged in 1974.

When it came to bargaining with the State government over severance terms, the trade unions were once again in an inferior power position. Hundreds of men were about to lose their jobs and the combined union committee was anxious to obtain the best terms. The trade unions had very few precedents to guide them. The State government was not prepared to be magnanimous. Governments and their treasury advisors are very conscious of precedent. The final severance deal was worth two weeks pay for every year of service up to a maximum of ten years. This was unjust for long serving Dockyard workers.

The twelve months to September 1977 saw about 1,150 workers at State Dockyard lose their jobs through no fault of their own. This paper has endeavoured to show that when redundancy is created, the power of workers to combat redundancy is very limited indeed. Major questions for society to answer are first, is such an imbalanced power structure fair and reasonable? Secondly, should most power be concentrated in the hands of a minority group, however named, to decide the destiny of the majority? 


\section{References}

Aungles, S. and I. Szelenyi (1979) Structural conflicts between the state, local government and monopoly capital - the case of Whyalla in South Australia The Australian and New Zealand journal of sociology 15(1): 24-35.

Commonwealth Employees (Redeployment and Retirement) Act 1979.

Daniel, W.W. (1970) Strategies for displaced employees P.E.P. Broadsheet 38(537), July.

Eldridge, J.E.T. (1968) Explanations of strikes. In his Industrial disputes London, Routledge and Kegan Paul.

Employment Protection Act 1975.

Federated Miscellaneous Workers' Union (SA) v Adelaide Milk Supply Co-Op Ltd, [1978] A.I.L.R. Case Nos 418 and 528.

Fisher, D.E. (1969) Redundancy and the law: some recent problems The journal of industrial relations 11(3): 212-222.

Gordon, B. (1977) The regional industrial relations system and the regional work force Newcastle, NSW Institute of Industrial Economics, University of Newcastle.

Herron, F. (1975) Labour market in crisis London, Macmillan.

Herron, F. (1972) Redundancy and redeployment from UCS 1967-71 Scottish journal of political economy XIX(3): 131-152.

I.A.C. (1976) (Industries Assistance Commission) Report, Shipbuilding Canberra, Australian Government Publishing Service.

Kahn, H. (1956) Repercussions of redundancy London, George Allen and Unwin.

Mackay, D.I. and G.L. Reid (1972) Redundancy, unemployment and manpower policy Economic journal 82(328): 1256-1272.

Mills, A.J. (1976) Worker sit-ins Personnel review 5(4): 46-50.

O.E.C.D. (1976) Measures of assistance to shipbulding Paris.

Paterson, P. (1978) Money not jobs Spectator April 22, p.13.

Pouncz, K. 1979 A survey of redundancy procedures Work and people 5(1): 7-12.

Sams, K.I. and J.V. Simpson (1968) A case study of a shipbuilding redundancy in Northern Ireland Scottish journal of political economy 15: 267-282.

Seglow, P. (1970) Reaction to redundancy: the influence of the work situation Industrial relations journal 1(2): 7-22.

Smith, A.D. (1966) Redundancy practices in four industries Paris, O.E.C.D.

Smith, P. (1978) Adjusting to change Canberra, Australian Council of Social Service. Wedderburn, D. (1965) Redundancy and the railwaymen Cambridge University Press.

Wedderburn, D. (1964) White collar redundancy: a case study Cambridge, Cambridge University Press.

Wood, S. (1977) A consideration of the study of redundancy Scottish journal of sociology 2(1): 52 .

Wood, S. (1977) Is redundancy a social problem? A comment Personnel review 6(3): 56.

Yerbury, D. (1973) Technological change and industrial relations in Australia Search 4: 251-256. 